Original article

\title{
Socio-spatial conflicts caused by an unfavourable rural structure and out-of-date
}

\author{
Land and Property Register
}

\author{
Agnieszka Głowacka1 ${ }^{1}$, Tomasz Noszczyk², Jarosław Taszakowski ${ }^{1}$, Józef Hernik ${ }^{2}$ \\ 1 Department of Agricultural Land Surveying, Cadaster and Photogrammetry, Faculty of Environmental Engineering and Land \\ Surveying, University of Agriculture in Krakow, Balicka Str. 253a, 30-149 Kraków, Poland \\ 2 Department of Land Management and Landscape Architecture, Faculty of Environmental Engineering and Land Surveying, \\ University of Agriculture in Krakow, Balicka Str. 253c, 30-149 Kraków, Poland \\ E-mail address: ( ${ }^{*}$ corresponding author): t.noszczyk@ur.krakow.pl
}

\section{ABSTRACT}

This article addresses the issue of conflict situations caused by an out-of-date Land and Property Register (LPR) and the disadvantageous structure of rural areas in southern Poland. In this part of the country, holdings are very fragmented and scattered, made up of a large number of small surface area plots located far from the headquarters of the holding. The aim of the article is to present actions that can help improve rural spatial structure and validity of the land register. The authors have, therefore, analysed the problems that may result in both spatial and social conflicts. The following were analysed in particular: discrepancies between data in the LPR and the existing factual state, plots without access to public roads, property ownership structure, the necessity to regulate property boundaries, and problems with the procedure for taking land out of agricultural production. The article presents both positive and negative effects of the land consolidation and exchange process, modernisation of the Land and Property Register, and their impact on socio-spatial conflicts. Its results indicated that the land consolidation procedure and LPR modernisation have a significant impact on socio-spatial relations in rural areas. It has been found that despite the fact that both these activities may give rise to new disputes in addition to resolving conflicts, the overall balance is positive. It is because more positive aspects of these actions were found than negative consequences.

KEY WORDS: cadastre, land consolidation, modernisation, agricultural management

ARTICLE HISTORY: received 14 July 2016; received in revised form 9 January 2017; accepted 20 January 2017

\section{Introduction}

The socio-political changes in Poland after the transformation period and later, upon accession to the EU, caused substantial changes in rural areas and land use structure (DANNENBERG \& KUEMMERLE, 2010). These processes are, however, unavoidable and determined by the growth of urbanisation, transport, and various services (WOCH \& WOCH, 2014). During this period, numerous social, economic, and environmental issues emerged in Polish villages (BAŃSKI \& STOLA, 2002). Note that rural areas are among the most problematic ones in the whole European Union because their social and economic structures are incapable of maintaining prolonged and intensive development (DUDZIŃSKA \& KoCUR-BERA, 2013).

There is a great spatial diversification of rural areas in Europe (VAN DIJK, 2003). Similar substantial disparity can be found at national, or regional levels (JANUS ET AL., 2016). For example, the average surface area of a plot in Poland is between 0.36 ha (southern Poland) to 2.54 ha (north-western Poland) (WoCH, 2010). Therefore, the spatial structure of rural areas in southern Poland is not favourable. It is dominated by great fragmentation and scattering of land, further escalated by a large number of plots comprising a single agricultural holding (JĘDREJEK ET AL., 2014; SORYS, 2013), which in turn determines agricultural property prices (KocUR- 
BERA, 2016). This condition can be improved mainly through the sale, or swapping of land, consolidation and exchange, structural pensions (pensions for transferring agricultural land to a larger holding) (LITWIN, 1997), or other activities funded by the EU, which is stressed by SORYS in his studies (2014). Such improvement and regulation of the agrarian structure has one more result: the introduction of order to landscape structures (HERNIK ET AL., 2013; LiTWIN, 1997).

The unfavourable rural structure and the outof-date Land and Property Register in Poland may provoke both social and spatial conflicts. According to BADERA (2010, p. 105), social conflict is defined as 'the process of mutual influence of entities with actual or imaginary clash of goals and interests'. The impact causes a change in actions taken or planned by the other side (BADERA, 2014). Sociospatial conflicts are a complex phenomenon with (existing or planned) spatial management being the primary bone of contention (DMOCHOWSKA-DUDEK, 2014). These conflicts definitely occur more often in urban areas, which is mainly a result of the concentration of various resources (capital, people, and infrastructure) (HENDERSON, 2005; WóJCIK ET AL., 2014). This does not mean that socio-spatial conflicts do not take place in rural areas. On the contrary, they do occur and involve various economic or social groups (residents, farmers, investors) (DMOCHOWSKA-DUDEK, 2014; IOJA ET AL., 2014) or result from various interests (DARLY \& TORRE, 2013). Conflicts in rural areas are often of a different nature to those in towns and result mainly from the openness of the landscape and the significant influence of environmental conditions on the development of production, service, and residential functions (HENDERSON, 2005; WóJCIK ET AL., 2014).
On the one hand, academic circles should assist local authorities and communities in preventing and resolving conflicts (HENLE ET AL., 2008). The relationship between sides of a conflict and local government, which is responsible for correct spatial planning, is one of the elements that shape local sustainable development (WóJCIK ET AL., 2014). It is also important that people whose responsibility it is to handle territorial development of rural areas are adequately educated and competent so that they can mediate and resolve existing conflicts (MAGEL, 2015). On the other hand, however, one should be careful when involving academics in the process of settling a conflict as their beliefs, or values, may be at variance with the interests of the local community. A conflict may escalate if academics are not only a source of information but also stakeholders involved in a socio-spatial conflict (HENLE ET AL., 2008).

The aim of this article is to discuss land consolidation and modernisation of the Land and Property Register (LPR) in the context of their impact on the improvement of rural spatial structure, validity of the LPR, and to avert sociospatial conflicts in the affected areas.

\section{Materials and methods}

\subsection{Study area}

The study area consists of selected cadastral districts in the Małopolskie voivodeship, southern Poland (Fig. 1). Małopolska is an interesting study area owing to its variable terrain (CEGIELSKA ET AL., 2017), hydrological and geological conditions (DRZEWIECKI ET AL., 2014), and first and foremost, the unfavourable spatial structure of its rural areas (JĘDREJEK ET AL., 2014; SORYS, 2013, 2014), which may give rise to various conflicts.

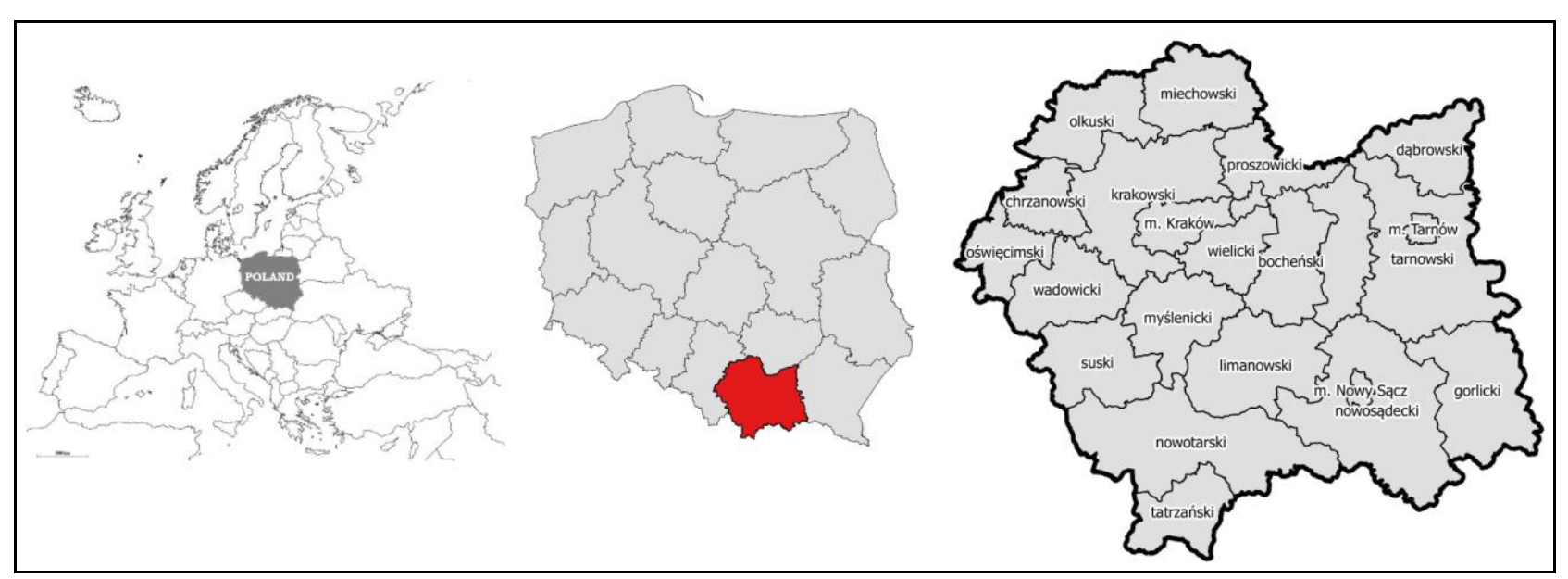

Fig. 1. Location of the Małopolskie voivodeship - study area (source: own elaborations) 
Agriculture in the Małopolskie voivodeship is dominated by small agricultural holdings comprising large numbers of plots with holdings whose area is below 1 ha constituting 38.5\% and holdings with a surface area of $1-5$ ha, $52 \%$ (SORYS, 2014). Note that Małopolska has disturbed relations between land, labour, and capital (SORYS, 2013). Small holdings are less profitable and generate greater production costs, which translates into smaller production volume. Heavy costs related to spatial parameters of these holdings result in the gradual cessation of farming in areas affected by this phenomenon (JANUS ET AL., 2016; KOCUR-BERA, 2016). This induces permanent 'setting aside' of these areas (DEININGER ET AL., 2012) and abandonment of the traditional land use (HERNIK ET AL., 2013).

\subsection{Data and methods}

Analyses involved data from land consolidation assumptions and the authors' own observations made during participation in the drafting of these documents for objects being prepared for application for EU funds under the present financial perspective of the Rural Development Programme (RDP) 2014-2020 for the Małopolskie voivodeship. Additionally, some elements of the consolidation documentation were used, in particular, detailed consolidation projects for the objects implemented in the previous financial perspective under the RDP 2007-2013 in the Małopolskie voivodeship.

Information and data on LPR modernisation were made available by the Michałowice Municipality Authorities and the geodesy service provider GEOPROF s.c., Kraków, which performed the modernisation. An interview with the deputy mayor of the rural commune provided valuable information as well.

The data on the actual use of land resulted from an in situ survey. Boundaries of individual types of land use are measured as a result of changes found prior to land estimation. Based on direct measurement, summaries of surface areas of individual types of land use are compiled and then compared with land use data from land and property register reports.

The article analyses results of a process of land consolidation and modernisation of the LPR with regard to eliminating, or provoking, socio-spatial conflicts.

\section{Results and discussions}

\subsection{Removal of discrepancies and updating register data in land consolidation}

When preparing assumptions for a consolidation project based on data from the LPR, land use studies are carried out. Then, as a result of the in situ survey, the results are juxtaposed with the actual land use. It often happens that these works expose numerous discrepancies resulting from a failure to update the register data on a regular basis. The Act on land consolidation and exchange imposes an obligation to update land use during the consolidation process. Figure 2 presents an example of land use discrepancy between register data and the existing state found in situ. The colourless areas on the right-hand side are registered as arable land, whereas the majority of them are forest lands, which are shown on the orthophoto map (Fig. 2).

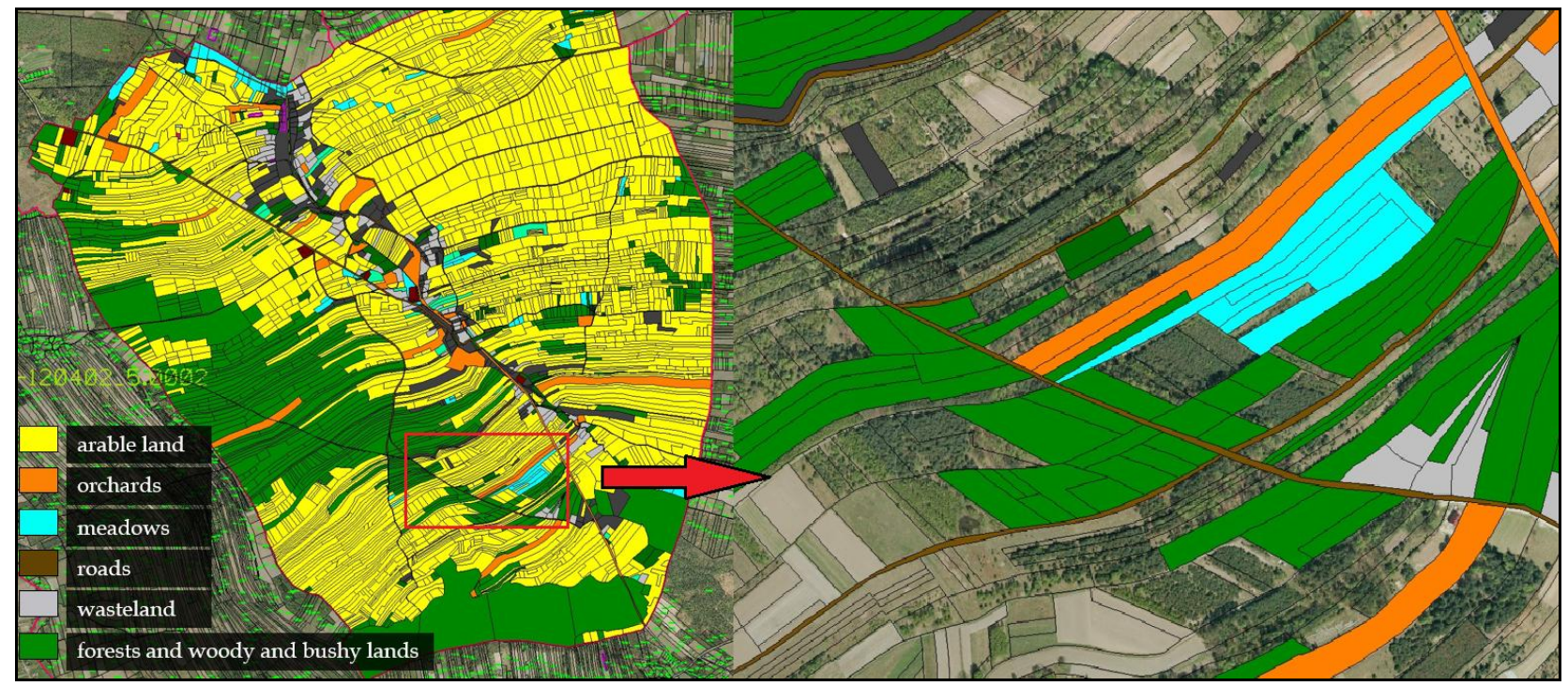

Fig. 2. Land use in the LPR and the actual land use have been marked on the orthophoto map (colours not included in the key do not influence analyses because the key aspect here is the occurrence of arable land in the LPR compared to the actual land use in situ) (after Janus \& Taszakowski, 2016) 
The discrepancies exemplify differences between the actual land use and data in the LPR. Updates during land consolidation result, not only in changed land use and quality class of land, but first of all bring changes in taxation. One of the greatest sources of income for local governments is property tax (PŁONKA \& WoJEWODZIC, 2008). Most changes involve the reclassification of agricultural land into built-up land. The least often reduced tax category is tax on buildings used for business purposes (PŁONKA \& WoJEWODZIC, 2008). Such operations result in social conflicts owing to increased property fees.

\subsection{Reduction of the number of plots without public road access}

Property access to a public road is one of the preconditions for streamlined (agricultural) land division (PoDCIBORSKI \& KIL, 2011). Property without access to a public road not only cannot be subject to this procedure, but is also hard to sell and use. Such cases necessitate an application of the rightof-way. This, in turn, requires the consent of owners of adjacent properties and legal separation of the land with the right-of-way. In an attempt to avoid additional administrative procedures, owners often consent to illegal transport through the property, which generates many social conflicts.

When assumptions for a consolidation project are being prepared, plot access to the public road system is analysed so that they have an access on at least one side. Plots without access to public roads are identified using descriptive and graphic data in the Land and Property Register report. The data is generated using specialist software for agricultural management works, Mk-Scal, which first generates a road network from descriptive data, verifies road classification against an orthophoto map, and then generates plots without direct access to a road based on geometric adjacency. Figure 3 shows examples of areas with no road access in several communes [gmina - thirdtier administrative unit] in the Małopolskie voivodeship. A new arrangement of plots and road system is designed in such a way during consolidation proceedings that the number of plots without road access is significantly limited.

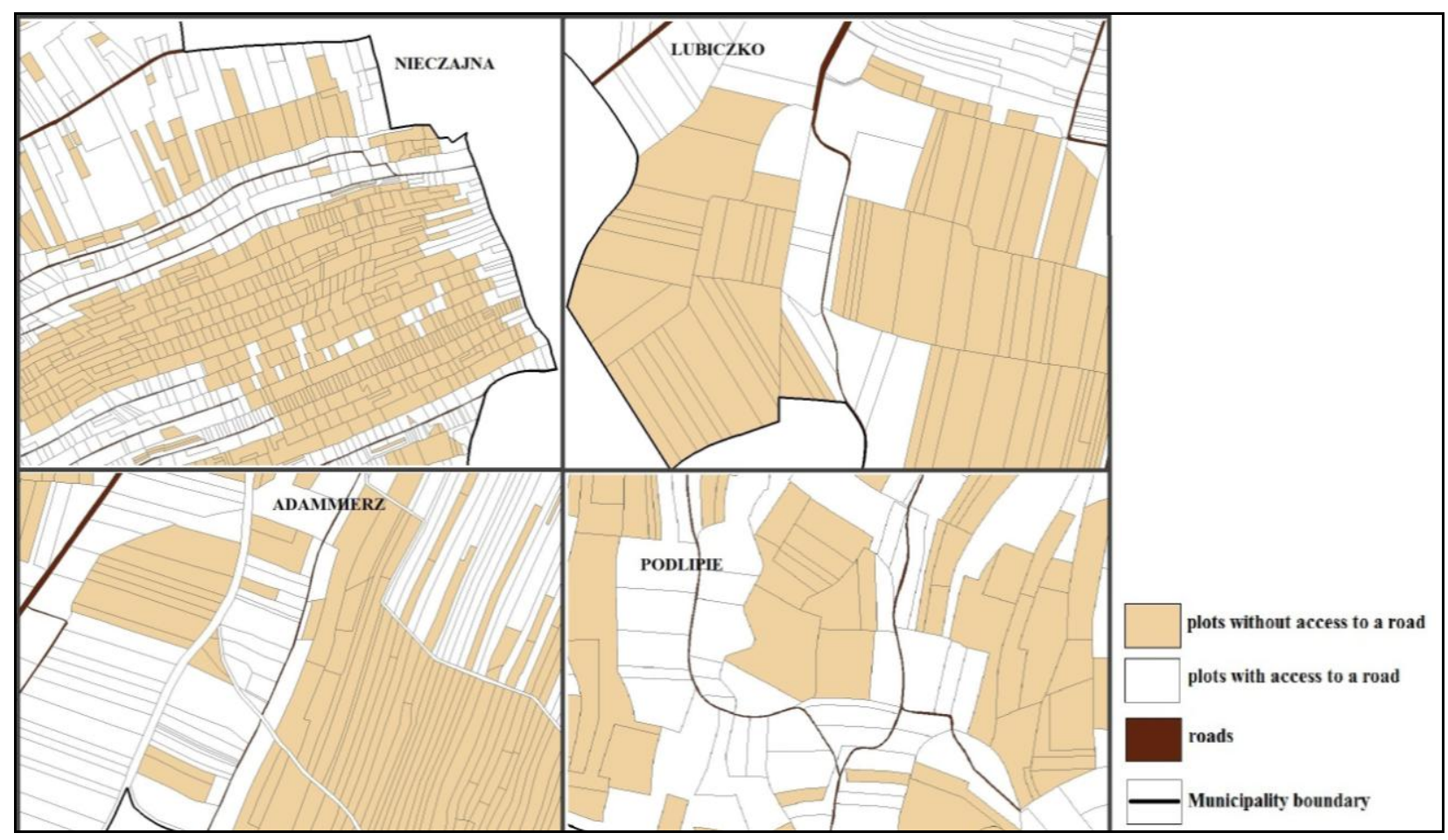

Fig. 3. Visualisation of plots without access to a public road (in beige) in selected villages in Małopolska (source: own elaborations)

Figure 4 shows a new land arrangement after consolidation, which provides access via a newly designed road system. Consolidation results in new plots whose shapes are different to those initially. New plot boundaries are designed with the intention of increasing their surface area, thus limiting the overall number of plots per holding.
The black boundaries in Figure 4 are boundaries determined and recorded in the presence of owners (these most often include roads, ditches, rivers, and built-up areas). Red lines are the boundaries designed during consolidation based on individual requests of consolidation participants as regards the future location of their land. 
Consolidation significantly affects the elimination of conflicts concerning illegal use of land to access property and minimises the necessity to apply the right-of-way.

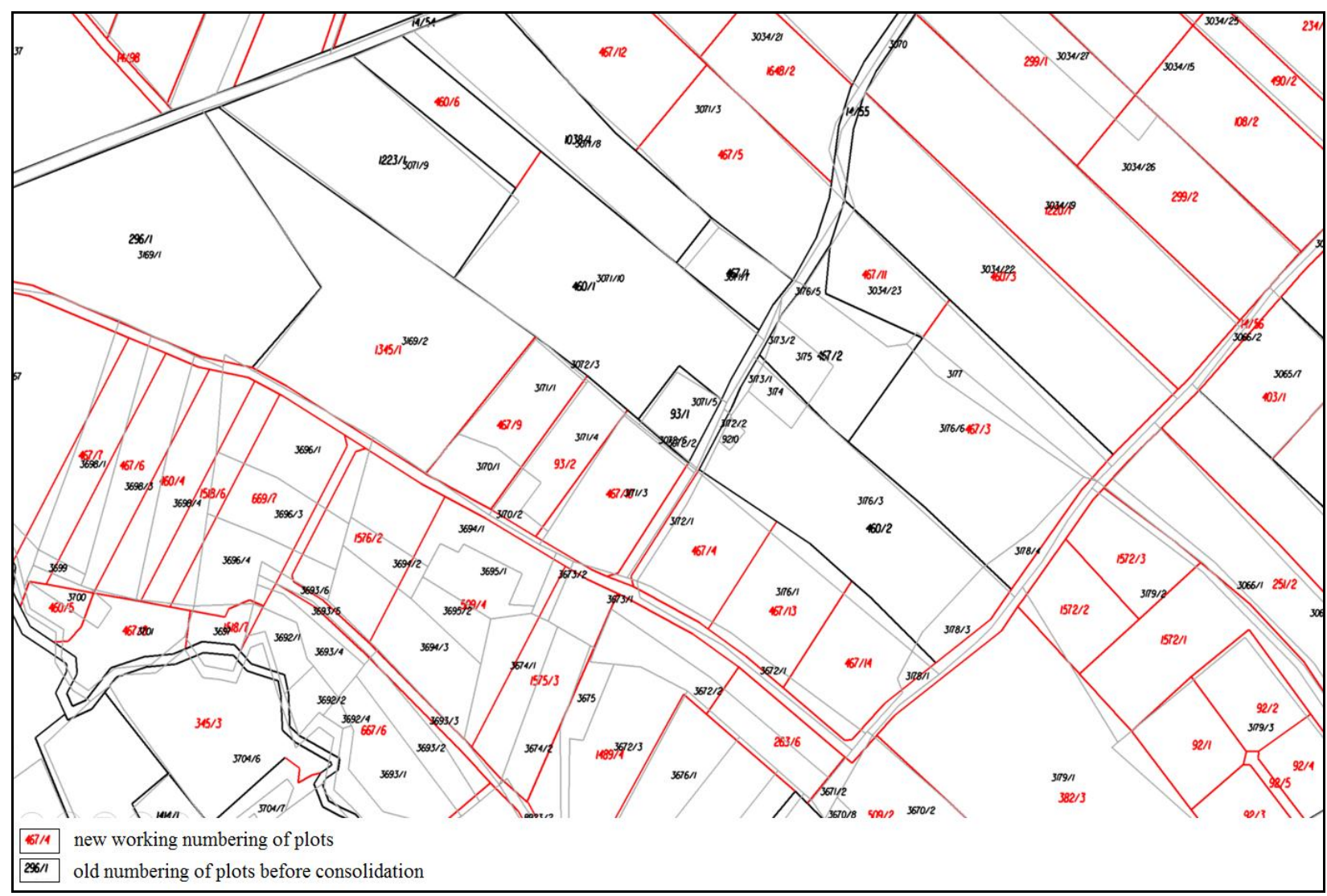

Fig. 4. Situation after consolidation - legal access to the public road system (source: own elaborations)

\subsection{Dissolution of joint ownership and implementation of inheritance decisions}

One of the elements of relative register data is the information on plot ownership structure, including joint ownership. High intensity of this phenomenon favours decisions to carry out comprehensive agricultural management works, such as land consolidation. Today, joint ownership is a common phenomenon of variable intensity. It is caused primarily by inheritance and failure to divide property at the final stage of inheritance proceedings.

In the Nowosądecki district [powiat - secondtier administrative unit] alone for over half of cadastre districts joint ownership concerns at least $15 \%$ of the total number of property units and in over a quarter of the districts $40 \%$ of properties are affected by joint ownership. The analysis determined that approximately half of the property units are community property. The other part of the joint ownership pool resulted from inheritance and the most common number of joint owners is 3-10.

Land consolidation may involve, upon a unanimous application of all joint owners, dissolution of joint ownership, implementation of inheritance decisions, division of property among heirs, and making entries into land and mortgage registers for the area subjected to the process. These activities facilitate adjustment of the current state of property ownership, but first of all eliminate family disputes regarding property and conflicts involving management or sale of joint property.

\subsection{Adjustment of boundaries in built-up areas}

The Act on land consolidation and exchange imposes an obligation to update register data, land use, and classes (UstawA, 1982). This is due to substantial discrepancies between data in register maps and orthophoto maps. The current actual state is different to the state in the register because the data is usually very old and can go back as far as the 1970s.

Apart from updating information about the actual land use, land consolidation involves adjustment of property boundaries for built-up areas, as long as it does not deteriorate property use conditions. It often happens that a boundary found in cartographic documentation actually intersects a building, or is substantially displaced in comparison to the actual in situ situation. This stems from the 
fact that boundaries recorded previously in the land register were determined during ownership determination between 1950-1970 when the LPR was being established. Determination of boundaries involved in situ measurement of land use status based on indications of concerned parties without the obligation to present legal documents by them. These are, therefore, not boundaries that specify the extent of ownership in situ in a legal sense (MALINA \& KOWALCZYK, 2011).

The consolidation procedure does not provide for the method of boundary determination other than designed boundaries and boundaries determined and recorded in situ. Boundaries determined by photogrammetric surveys or vectorisation may not be used.

In the context of resolving conflicts related to boundaries, consolidation offers a tool for recorded boundary determination in situ if concerned parties are unable to agree on a boundary, which prevents delineation, and may take years of legal proceedings. Only at this stage of boundary determination may concerned parties be offered ready-made design solutions involving the equivalent exchange of surface area differences, or cash compensation. This is its advantage over other geodesic procedures regarding boundaries. Figure 5 shows examples of corrected property boundaries found in the register.
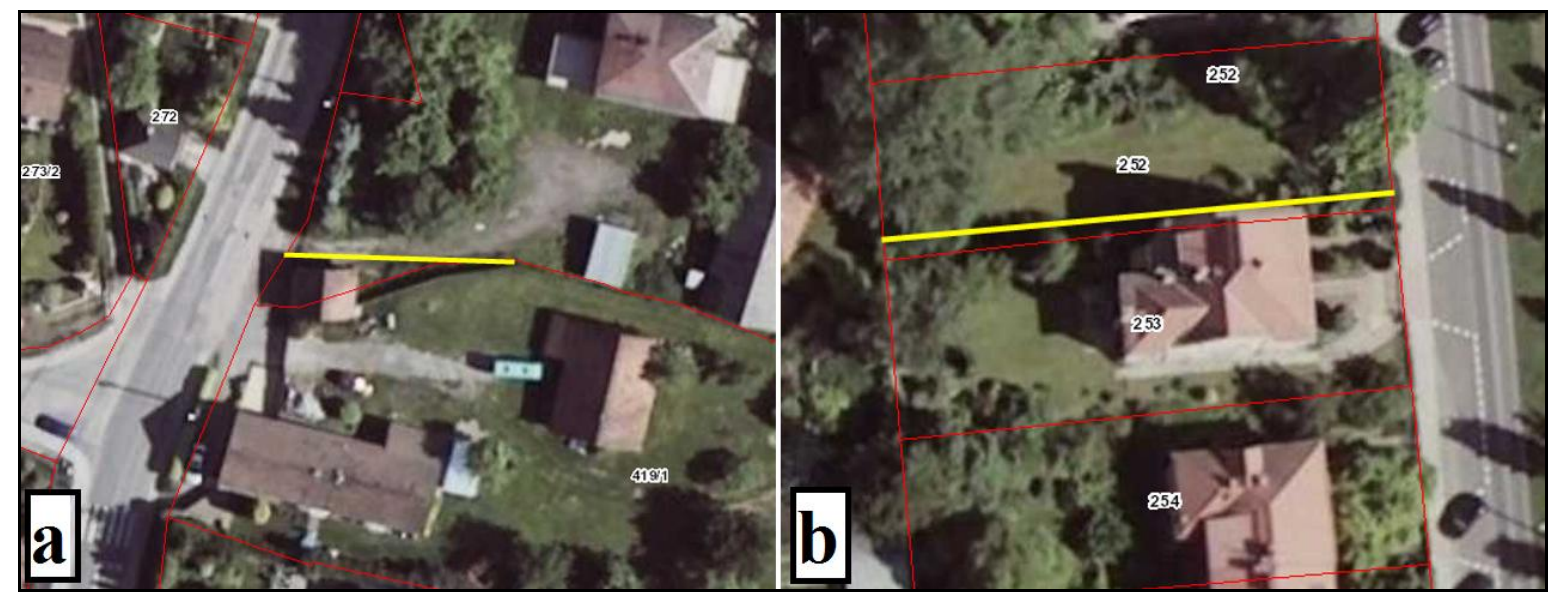

Fig. 5. Adjustment of built-up property boundary as per the actual state: $\mathrm{a}$ - along the fence, $\mathrm{b}$ - correction of a boundary intersecting a building (source: own elaborations)

After the adjustments, the changes are introduced to the LPR. Adjustment of property boundaries involves the necessity to divide it and transfer the title with a notary deed in an exchange of land between owners or a sale transaction. The procedure may be included in a consolidation process where a property boundary is finally determined and recorded and the resulting changes do not require notary intervention but a land or cash equivalent.

\subsection{Improvement of register data validity by modernisation}

In Poland, there are many differences between LPR data and the existing in situ state. It often happens that built-up, or wooded and bushy plots, are registered in the LPR as arable land (Fig. 2). This often leads to conflicts as the tax authority calculates property tax using data in the LPR and owners' declarations for tax purposes, and applies the tax rate for agricultural land despite the plot being built-up (DAWID, 2012). Consequently owners of property with similar surface area and value pay different taxes and the municipality incurs a loss (MIKA ET AL., 2015).
This point was noted by, among other authorities, the municipality of Michałowice near Kraków, which decided to modernise the LPR with its own resources despite it being a statutory duty of the starost. This way the mayor of the rural commune wanted to apply just taxes to all residents, as per the actual land use. The modernisation unravelled significant discrepancies between the existing state and register data: more than half of the buildings were not registered for taxation, for example. These discrepancies were described in detail by NOSZCZYK \& HERNIK (2016), who listed positive and negative results of the modernisation in Michałowice. It is worth noting that the investment in the modernisation of the LPR in the amount of PLN 570 thousand paid for itself within a year as the increase of property tax was PLN 700 thousand year-on-year. This resulted in a significant reduction of property tax rate: initially from PLN 0.45 to PLN 0.27 per $1 \mathrm{~m}^{2}$ of land (2014) and to PLN 0.23 per $1 \mathrm{~m}^{2}$ in 2016 and is the lowest tax in the Kraków district (Tab. 1) (MIKA ET AL., 2015; NOSZCZYK \& HERNIK, 2016). 
Table 1. Tax rates in Krakow and selected communes of the Krakow district (powiat) in 2016 (source: Own work based on information on Municipalities' websites)

\begin{tabular}{|l|c|c|}
\hline \multicolumn{1}{|c|}{ Commune } & Other land [PLN·m $\left.{ }^{-2}\right]$ & $\begin{array}{c}\text { Other buildings, including garages, } \\
\left.\text { storage buildings [PLN·m }{ }^{-2}\right]\end{array}$ \\
\hline Michałowice & 0.23 & 3.34 \\
\hline Zielonki & 0.34 & 4.73 \\
\hline Słomniki & 0.30 & 4.86 and 7.42 \\
\hline Kocmyrzów-Luborzyca & 0.31 & 4.10 \\
\hline Mogilany & 0.31 & 6.05 and 3.55 (barns) \\
\hline Kraków & 0.47 & 7.68 \\
\hline The maximum tax rates & 0.47 & 7.68 \\
\hline
\end{tabular}

Results of the modernisation initiated some controversies among residents of the community. Those whose taxable property area, or number of buildings, subject to taxation increased significantly were not happy with the solution. The mayor strove to reduce social conflicts and remitted part of the payable tax with an administrative decision. This brought the expected results. The local community accepted the new situation and corrected statuses of their property by leasing, demolishing, or selling unnecessary utilities or farm buildings.

\subsection{Problems caused by the procedure to take land out of agricultural production}

Possible socio-spatial conflicts can arise in relation to the procedure of taking land out of agricultural production. Pursuant to Article 12a of the Act on protection of arable land and forests (USTAWA, 1995) it is possible to take up to 0.05 ha out of production for single family development free of charge. This results in investors purposefully taking out property up to 0.05 ha to avoid relevant annual payments and charges despite the fact that the actual built-up area is larger. Still, it is registered as agricultural land. Therefore, owners of such agricultural land pay tax calculated using rates for agricultural land, which is much lower than their neighbours who have taken out the whole built-up plot as required and pay a higher property tax (NOSZCZYK \& HERNIK, 2016). Moreover, it is not clear when land is actually taken out of agricultural production. There is, therefore, doubt as to when to register this fact in the LPR (FELCENLOBEN, 2009). These problems result in delays in updating tax registers, which entails erroneous and unfair taxation (MIKA ET AL., 2015). Hence, this article calls for the necessary changes in legislation that would eliminate the inconsistencies and specify the actual moment of taking of land out of agricultural production by defining a directory of events that mark commencement of a different land use (NIK, 2012).

\section{Conclusions}

Multifunctional development, determined to be the primary strategic goal of rural development in Poland will induce an increase in socio-spatial conflicts (WóJCIK ET AL., 2014). Broadly defined agricultural management works should ensure multiple regulations for property, which are strictly related to socio-spatial interrelations in addition to their main purpose of updating and improving land structure.

To conclude, land consolidation and modernisation of the LPR may significantly influence socio-spatial relations (Fig. 6). On the one hand, they will considerably inhibit the occurrence of any socio-spatial conflicts, and on the other hand, may cause new social disputes related mainly to the increase of taxable property surface area.

The final result is, however, positive. There are notably more constructive results of land consolidation and modernisation of the register for the public and space than disadvantages and limitations. Ultimately, the new spatial structure of land and updated property registers and databases facilitate the more efficient sale and division of property, and above all, better management.

\section{Acknowledgements}

This research was financed by the Ministry of Science and Higher Education of the Republic of Poland. The authors would like to thank to the reviewers for all of very valuable and helpful comments. 


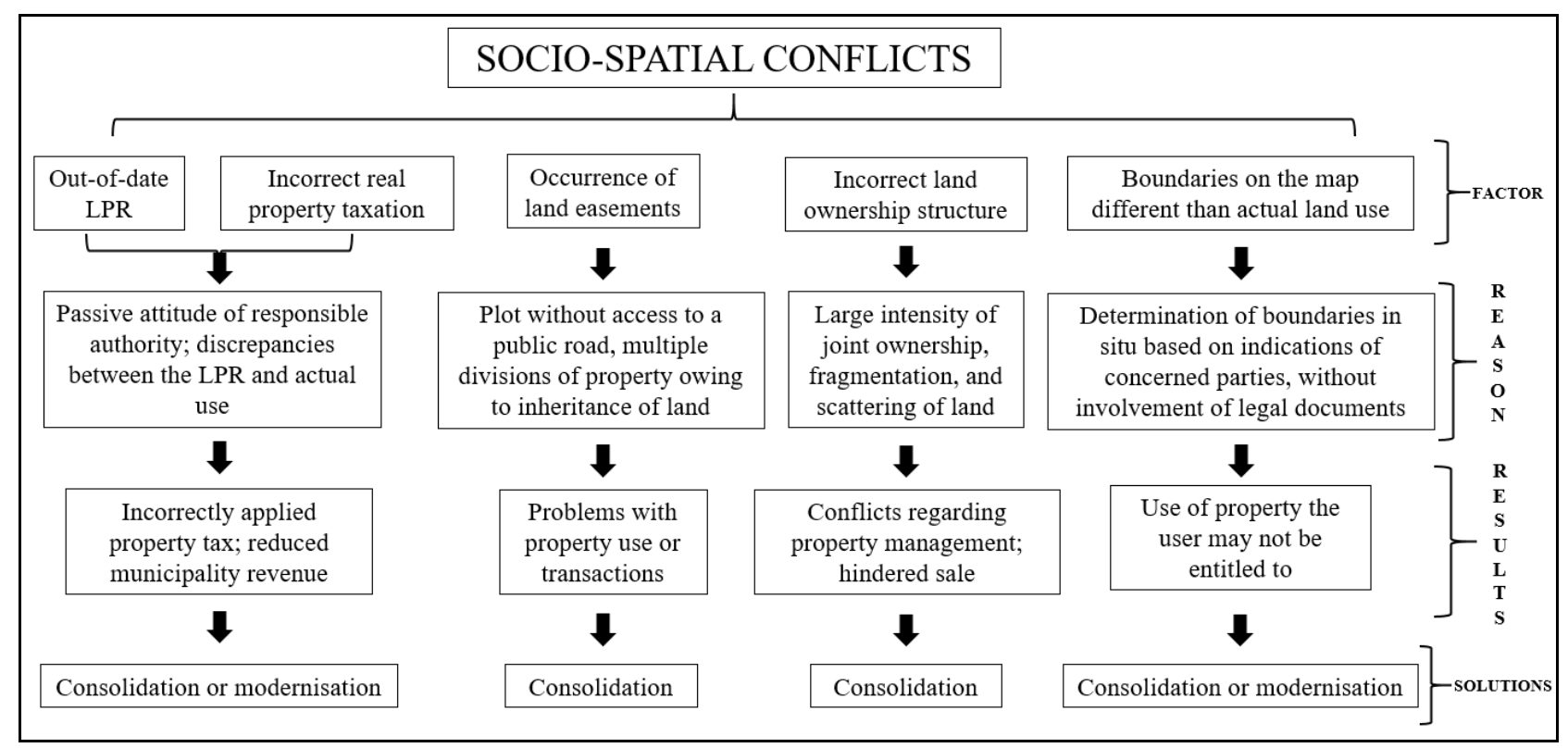

Fig. 6. Classification of the socio-spatial conflicts (source: own elaborations)

\section{References}

Badera J. 2010. Social conflicts on the environmental background related to development of mineral deposits in Poland. Mineral Res. Manage., 26(1): 105-125.

Badera J. 2014. Problems of the social non-acceptance of mining projects with particular emphasis on the European Union - a literature review. Environ. Socio-econ. Stud. 2(1): 27-34.

Bański J., Stola W. 2002. Przemiany struktury przestrzennej i funkcjonalnej obszarów wiejskich w Polsce. Studia Obszarów Wiejskich, 3, PTG, IGiPZ PAN, Warszawa.

Cegielska K.M., Salata T., Gawroński K., Różycka-Czas R. 2017. Level of spatial differentiation of anthropogenic impact in Małopolska. J. Ecol. Eng., 18(1): 200-209.

Dannenberg P., Kuemmerle T. 2010. Farm Size and Land Use Pattern Changes in Postsocialist Poland. Prof. Geogr., 62(2): 197-210.

Darly S., Torre A. 2013. Conflicts over farmland uses and the dynamics of "agri-urban" localities in the Greater Paris Region: an empirical analysis based on daily regional press and field interviews. Land Use Policy, 33: 90-99.

Dawid L. 2012. Problems connected with using data from real estate cadastre in tax aims on the example of the chosen rural community. Infrastructure and Ecol. Rural Areas, 1/III/2012: 7-17.

Deininger K., Savastano S., Carletto C. 2012. Land Fragmentation, Cropland Abandonment, and Land Market Operation in Albania, World Dev., 40(10): 2108-2122.

Dmochowska-Dudek K. 2014. Konflikty społeczno-przestrzenne jako nowy przedmiot badań geografii społecznej. [in:] Maik W., Rembowska K., Suliborski A. (eds.) Dorobek polskiej geografii po konferencji w Rydzynie. Ocena krytyczna, Wyd. Uniw. Łódzkiego, Łódź: 145-153.

Drzewiecki W., Wężyk P., Pierzchalski M., Szafrańska B. 2014. Quantitative and Qualitative Assessment of Soil Erosion Risk in Małopolska (Poland), Supported by an Object-Based Analysis of High-Resolution Satellite Images. Pure Appl. Geophys., 171(6): 867-895.

Dudzińska M., Kocur-Bera K. 2013. Rural areas in Poland, Austria and Czech Republic - comparative analysis. Infrastructure and Ecol. Rural Areas, 1/IV/2013: 71-83.
Felcenloben D. 2009. Exclusion of Land from Agricultural Production in the Context of the Update of the Land and Buildings Records. Samorzad Terytorialny, 4: 61-68.

Henderson S.R. 2005. Managing land-use conflict around urban centres: Australian poultry farmer attitudes towards relocation. Applied Geography, 25(2): 97-119.

Henle K., Alard D., Clitherow J., Cobb P., Firbank L., Kull T., McCracken D., Moritz R.F.A., Niemelä J., Rebane M., Wascher D., Watt A., Young J. 2008. Identifying and managing the conflicts between agriculture and biodiversity conservation in Europe-A review. Agr. Ecosystems \& Environ., 124(1-2): 60-71.

Hernik J., Gawroński K., Dixon-Gough R. 2013. Social and economic conflicts between cultural landscapes and rural communities in the English and Polish systems. Land Use Policy, 30(1): 800-813.

Ioja C.I., Nita M.R., Vânau G.O., Onose D.A., Gavrilidis A.A. 2014. Using multi-criteria analysis for the identification of spatial land-use conflicts in the Bucharest Metropolitan Area. Ecol. Indic., 42: 112-121.

Janus J., Głowacka A., Bożek P. 2016. Identification of areas with unfavorable agriculture development conditions in terms of shape and size of parcels with example of Southern Poland. Proceedings of $15^{\text {th }}$ Int. Sci. Conf:: Engineering for Rural Development, Jelgava, Latvia, 15: 1260-1265.

Janus J., Taszakowski J. 2016. Ocena struktury przestrzennej obszarów wiejskich województwa małopolskiego $w$ aspekcie zapotrzebowania na prace scaleniowe. Wyd. Uniwersytetu Rolniczego, Kraków.

Jędrejek A., Woch F., Szymański L. 2014. The assessment of break-up of farms for the needs of determination of the scope of land consolidation works in Poland. Przegl. Geodezyjny, 86(10): 3-10.

Kocur-Bera K. 2016. Determinants of agricultural land price in Poland - a case study covering a part of the Euroregion Baltic. Cah. Agric., 25: 25004.

Litwin U. 1997. Synergiczne uporządkowanie struktur krajobrazowych na przykładzie Kotliny Mszańskiej. Zesz. Nauk. AR w Krakowie, seria: Rozprawy, 225.

Magel H. 2015. Where is the Rural Territorial Development Going? Reflections on the theory and practice. Geomatics, Landmanagement and Landscape, 1: 55-67. 
Malina R., Kowalczyk M. 2011. Geodezja Katastralna. Wyd. Gall, Katowice.

Mika M., Kwartnik-Pruc A., Leń P., Bielska A., Oleniacz G., Dawid L., Deska K., Trembecka A. 2015. Wybrane zagadnienia kształtowania katastru nieruchomości w Polsce. Współczesne problemy i trendy. Wyd. Uniw. Rolniczego, Kraków.

NIK 2012. Informacja o wynikach kontroli: Wyłączanie gruntów z produkcji rolniczej i jego skutki dla ewidencji podatkowej w gminach w latach 2007-2012. P/11/141, nr ewid. 156/2012/P11141/LKR. http://geoforum.pl/ upload/files/pliki/kontrola_nik.pdf [dostęp 17.06.2016].

Noszczyk T., Hernik J. 2016. Kompleksowa modernizacja ewidencji gruntów i budynków. Acta Sci. Pol., Formatio Circumiectus, 15(1): 3-17.

Płonka A., Wojewodzic T. 2008. The real estate tax policy of communes from Małopolska Region. Zesz. Naukowe SGGW - Ekonomika i Org. Gosp. Żywnościowej, 65: 201-209.

Pociborski T., Kil J. 2011. Spatial order of peripheral areas in aspects of partition. Barometr Regionalny, 3(25): 79-84.

Sorys S. 2013. The dynamics of changes in rural areas. Probl. Drobnych Gospodarstw Rolnych, 1: 87-99.
Sorys S. 2014. The Impact of European Funds on the Development of Rural Areas in Małopolska - Expectations and Opportunities. Geomatics, Landmanagement and Landscape, 1: 79-93.

Ustawa z dnia 26 marca 1982 r. o scalaniu i wymianie gruntów (tekst jedn.: Dz.U. z 2014 r., poz. 700 ze zm.).

Ustawa z dnia 3 lutego 1995 r. o ochronie gruntów rolnych i leśnych (tekst jedn.: Dz.U. z 2015 r., poz. 909 ze zm.).

van Dijk T. 2003. Scenarios of Central European land fragmentation, Land Use Policy, 20(2): 149-158.

Woch F. 2010. The current status and possible changes of extension of farms in Poland. Przegl. Geodezyjny, 82(9): 10-17.

Woch F., Woch R. 2014. Changes in rural areas utilization in Poland. Infrastructure and Ecol. Rural Areas, I/1/2014: 111-124.

Wójcik M., Dmochowska-Dudek K., Traczyk A. 2014. Konflikty społeczno-przestrzenne na obszarach wiejskich województwa łódzkiego. Biul. Krajowej Sieci Obszarów Wiejskich Woj. Łódzkiego, 4: 8-11. 